\title{
Is National Government a Threat to Devolved System of Governance in Kenya?
}

\author{
Doreen Nekesa Busolo \\ PhD Candidate, Centre for Communication and Social Change, School of Communication \& Arts, University of \\ Queensland, Australia \\ Samuel Ngigi, $\mathrm{PhD}$ \\ Lecturer at School of Journalism and Mass Communication, University of Nairobi
}

\begin{abstract}
This paper addresses the ways through which the national government of Kenya has proved to be a threat to devolution. Challenges emanating from national government actions are hampering the implementation of devolution. Devolution was intended to bring services closer to the people and promote public participation in decision-making. Transfer of functions from the national government to county governments and resource allocation to counties as provided for in the constitution 2010 is core to the implementation of devolution. Public participation permitted communities to manage their own affairs and further their development agenda. The minority and marginalized communities are recognized and protected through a devolved system of government as provided for in Article 174 of the constitution. The issue of inequality which was strongly practiced by the centralized system of governanceshouldbe addressed through devolution. There has been the development of national laws and policies other than devolution laws that were developed on the onset of the devolved system of governance. These laws affected the implementation of devolution. Budget Policy Statement according to the National Treasury (2013) is to accelerate economic growth by sustaining macroeconomic stability; focusing on economic policies and structural reforms; and deepening investment in critical economic infrastructure. The BPS is published under Section 25 of the Public Finance Management Act. However, the national budget policy statement is framed in a manner they encroach county functions mandates. Judiciary has the important role of giving effect to the constitutional provisions on devolution; however, the independence of the judiciary is threatened by political quarters affecting its function in the implementation of devolution. Commissions and independent offices whose collective responsibility to facilitate the achievement of devolution is impaired due to underfunding. Poor intergovernmental consultations are affecting devolution in the sense that plans to undertake Nairobi City County functions without due process and intergovernmental agreements are infringing on the Intergovernmental Relations Act, 2012. Above these challenges, the national government has enacted laws to reduce the power of independent institutions, direct intimidation, and incapacitation through budgetary cuts.
\end{abstract}

DOI: $10.7176 / \mathrm{PPAR} / 10-7-05$

Publication date:July $31^{\text {st }} 2020$

\subsection{Introduction}

The devolved system of governance marked its sixth anniversary in March 2018 since it came into effect after the March 2013 general elections. The main function of devolution was to bring essential services closer to the people through the transfer of functions to the County Governments. Some of the legislation and policies to implement devolutions were established before the onset of the devolved system of governance and more policies were developed to facilitate the devolution process.

Allocation of resources to County Governments aimed at promoting equitable, efficient, and prudent utilization of public resources and also to facilitate theimplementation of the devolution. Ministry of Devolution and Planning was instrumental in establishing the counties' operational units, including the County Executives and Assemblies through the provision of staff. On the other hand, the National Treasury is to deliverfiscal capacities in counties. It is the mandate of the Senate to protect the fiscal and administrative interests of the counties as provided for in Article 96 (KIPPRA 2016)

The promotion of social and economic development through public participation as provided for in Article 174 of the constitutionshould be a continuous process of devolution. This will enhance government responsiveness to the needs of the citizens as well as the inclusion of the public in decision-making. The communities are given the power to manage their own affairs and further their development thus promoting self-empowerment. As a result, the devolved system of governance recognizes and promotes the interests and rights of minorities and marginalized communities.

Although the transfer of power and functions is constitution obligation, Article 187 emphasize that the transfer offunctions must be done through mutual agreement to prevent conflict between the national and county governments. Enactment of laws as well as the establishment of intergovernmental institutions together with their mandate was arrived at to enhance the achievement of devolution. 
The implementation of the devolved system of Government has experienced policy, institutional, legislative, administrative, budgetary, and program challenges as reported by the Ministry of Devolution and Planning Policy (2016). However, the major threat affecting the achievement of devolution as pointed out by TISA (2018) is emanating from the National government. There have been several national government actions that threaten the substratum of devolution and due to this, there is a need to protect devolution.

According to the Ministry of Devolution and Planning (2016), operations and execution of devolved functions have faced a couple of challenges that led to the formation of devolution policies to help address those issues. Although the policy was established, the Ministry of Devolution and Planning pointed out that "there have been incessant structural challenges affecting the smooth running of county governments". These include; late disbursement of funds, supremacy issues between the Senate and National Assembly, double taxation, automation of revenue collection at the counties, strained intra-governmental relations, intergovernmental challenges among others.

The speech of the chairman of Council of Governors H.E JosphatNanok during the induction of governors and deputy governors in December 2017 affirms that there is a need for an enabling environment for governors to deliver their mandate. "We are not there yet, but with a strong enabling environment, County Governments have the capacity to spur huge economic and social dividends that will lead this country into a first-world nation".

\subsection{Background}

The supreme law of the land, the Constitution of Kenya 2010 ushered in the devolved system of government. Devolutionas defined by the constitution consists of two distinct and interdependent levels of government that are required to work in cooperation and consultation (Article 6(2)). Thetwo levels of government, namely the National and County Governmentshave the autonomy to the extent that the constitution allocates functions and powers to both of them (Ministry of Devolution and Planning 2016).

Article 189(a) emphasizes that thegovernments at either level are required to perform its functions and exercise its powers in a manner that respects the functional and institutional integrity of government at the other level. The functions of both governments are categorized into three; i.e. functions exclusive to the level of government, those that are concurrent, and those that are residual.

The National Government comprises the National Executive, Parliament, and the Judiciary while the County Government comprises the County Executive and County Assembly. The implementation of devolution is a collective responsibility of the following state organs: parliament and the legislative assemblies in the county governments, the National Executive, the executive structures in the County Governments, the Judiciary, and Independent Tribunals, Commissions and Independent Offices (Ministry of Devolution and Planning 2016). The principal secretary, state department of devolution in her speech during the inter-ministerial workshop on $14^{\text {th }}$ April 2016 affirms that "chapter two sec. 6(3), of the constitution, states that national state organs shall ensure reasonable access to its services in all parts of the republic."

Devolution system of governance aimed at promoting social and economic development, easy access to services, and promotion of equitable distribution of resources. The adoption of the devolved system changed the governance system where there was a separation of powers and a system of checks and balances (Ministry of Devolution and Planning 2016). Some of the laws that were developed to guide the transition to the devolved system of government are County Government Act 2012, Transition to Devolved Government Act 2012 , Intergovernmental Relations Act 2012, Urban Areas and Cities Act 2011, Public Finance Management Act 2012, Transition County Allocation Revenue Act 2013 and County Public Finance Management Transition Act 2013.

The devolution process started in 2013, and during this period, there has been the enactment of relevant laws, operationalization of County Government structures, transfer of functions and responsibilities, as well as the allocation of resources (Ministry of Devolution and Planning 2016). Each of these laws was enacted to create strategies for the implementation framework and the adoption on which objectives of devolution can be achieved. Furthermore, the laws make an important contribution to our understanding of the devolved system of governance.

Through public participation, the citizens are empoweredto inculpate inthe legislative and other business of parliament and its committees. Parliament is required to enact legislation providing for the powers, privileges, and immunities of county assemblies, their committees, and members(Kenya Law Reform Commission 2017).

This point is also sustained by Article 1(2) of the constitution 2010 which states that all sovereign power belongs to the people of Kenya and it further emphasizes that the people may exercise their sovereignty directly or through their elected representatives. Article 174 provides for the participation of the public in the exercise of the powers of the state and the making of decisions affecting them.

This interpretation steers the decentralization of power which aims at improving local governance and service delivery through responsive institutions. The constitution provides the mandate to various institutions involved in the implementation of devolution. Scholars agree that a decentralized system of government is more likely to result in enhanced efficiency and accountability than its centralized counterpart (White, 2011).

Implementation of the devolved system is a process that started in 2013 and according to the Ministry of 
Devolution and Planning (2016), Ngigi and Busolo (2019), there have been a success as well as challenges experienced in the course of implementing devolution. It is against this experience that a policy on the implementation of the devolved system of government to respond to the emerging challenges in the implementation of devolution was developed. The purpose of this policy is to improve the implementation of the devolved system of government to achieve optimal service delivery.

\subsection{CHALLENGES/THREATS}

The transition to the devolved system of governance was highly anticipated although there were concerns that there might be reluctance from the central government to implement devolution fully. There was also a concern that the governors and county-level governments would be weak, and that they would need strong constitutional protection for devolution to succeed (ICDL 2016). However, this was managed through the constitution, where laws were established to enhance and also to oversee the achievement of devolution.

County governments as stated by ICDL (2016) have proven themselves to be strong and capable of effectively fighting to protect the devolved institutions. This strength has in turn called into question the roles of senators and MPs, leading to the second round of attempts from the central government to regain powers at the county level. The struggle between national and county governments has not been resolved.

ICDL (2016) report revealed that the Jubilee government dragged its feet on implementing devolution. Although the Sixth Schedule to the Constitution provides for the reconstruction of provincial administrations, the Jubilee government protected the old provincial administration and left it in place.

Devolution in Kenya has experienced many challenges however challenges emanating from the national government are greatly affecting the function of county governments. The constitution permitted all levels of governments to perform its functions and exercise its powers in a manner that respects the functional and institutional integrity of government at the other level and respects the constitutional status and institutions of government at the other level (Ministry of Devolution and Planning 2016).

1.2.1 Numerous national legislative bills proposing measures that will encroach the devolution structure as provided in the constitution.

The following state organs have the mandate and collective responsibility to enhance the achievement of the objects of devolution as stipulated in Article 174; The parliament and the legislative assemblies in the county governments, the National Executive, the executive structures in the County Governments, the Judiciary and Independent Tribunals, Commissions and Independent Offices.

The devolution laws include: County Government Act 2012, Transition to Devolved Government Act 2012, Intergovernmental Relations Act 2012, Urban Areas and Cities Act 2011, and Public Finance Management Act 2012. Due to challenges experienced immediately the devolved system of governance was introduced, more policies were enacted to enhance the implementation of devolution. Other Acts passed to operationalize the devolved system of government include the Transition County Allocation Revenue Act 2013 and County Public Finance Management Transition Act 2013.

Report by the Council of governors together with UNDP (2015) onsectoral policy and legislative analysis revealed the development of national laws and policies which affect counties without the effective consultation of county governments. This was a major concern for the county government since it affects the process of devolution. According to the Constitution (2010), governmental functions that affect either level of the government should be carried out in the spirit of consultation and cooperation, without which, implementation will be met with challenges and lack of proper coordination.

Despite the adoption of the devolved system, in the transition period, most of the functions which county governments were to perform were managed through national government institutions (CoG and UNDP 2015). Lack of consultation between the National and County government has a major impact on the devolution process although Intergovernmental Relations Act (IGRA) was passed in 2012 before county governments were elected into office; meaning the challenge was anticipated and measures put in place however implementation was lacking.

Policy on the devolved system of government is a policy on the implementation of the devolved system of government. The first objective of this policy is to harmonize laws and policies that are inconsistent with the devolved system of government. The goal of devolution policy is to address the emerging issues in the implementation of devolution and to provide policy measures to enhance effective governance at both levels of government.However, the political and institutional culture of centralized governance, built over 50 years, seems to frustrate efforts to pave way for county governance.

It is important to note however that, the launch of the Policy on Devolved System of Government on $29^{\text {th }}$ March 2017 aimed at harnessing the gains of devolution by addressing the challenges and gaps identified in the first phase of the implementation of devolved system of government in Kenya by including harmonization of laws, alignment of roles and coordination and collaboration among two levels of government, non-state actors and citizens

Besides, it is important however not to assume laws that were enacted before the promulgation of the 
constitution that established several institutions whose functions are now devolved under the Fourth Schedule of the constitution. As a result, there is a conflict of laws and a conflict between the two levels of government and the duplication of roles. For example, some Regional Development Agencies continue to perform functions that are listed as county functions (ministry of devolution and planning 2016). According to The Institute of Social Accountability (TISA 2018), measures proposed through numerous national legislative bills have encroached the devolution structure as provided in the constitution.

Moreover, the Transition Authority (TA) was established in July 2012 and was mandated to facilitate and coordinate the transition to the devolved system of government. A report by Business Daily (2014) "Delays by Transition Authority Frustrating Devolution, says Commission for the Implementation of the Constitution (Kenya) "accusedTA of dragging the process by failing to give a clear definition of components of the functions to be transferred to the counties as well as their costing. The report further stated that none of the reports handed to the commission by TA contains the status of unbundling of functions and costing, which is causing hitches to Constitution implementation. CIC warned that failure by TA to follow the laid down processes is setting up the country for conflict between the county and national governments.

Report by the Ministry of Devolution and Planning (2016), emphasized on the same issue that was raised by CoG in 2014 when it stated that section 7 of the Transition to Devolved Government Act 2012 (TDGA, 2012) required the Transition Authority to facilitate the analysis and phase transfer of functions provided under the Fourth Schedule of the Constitution. The TA was required to develop a framework for comprehensive and effective transfer of under section 15 of the Sixth Schedule to the Constitution. However, while the framework was developed, the transfer of devolved functions did not comply with the criteria provided within that framework. This means counties may have received functions for which they could not implement.

The law provides for the function of the power of a government at one level to be transferred to a government at another level by an agreement between the governments if the function or power is effectively performed by the receiving government in Article 187. However, there is no legal framework to support these provisions as the report by the Ministry of Devolution and Planning (2016) revealed. One of the objectives of the Ministry of Devolution and planning is to monitor and evaluate the implementation of policies through monitoring and evaluation.

1.2.2 The national budget policy statement framed in a manner that encroaches county functional mandates Every year, County governments are required by the law to submit Budget Policy Statement and the Revenue Bills to Parliament by February. This process comprises county budget review and outlook paper, and budget estimates, among other requirements, must be submitted during this time. Thereafter, county governments are informed of their allocation. It is however important to note that, finance laws and finance bills are passed on an annual basis by Parliament (The national Treasury 2013).

2013 was the fifth Budget Policy Statement (BPS) to be tabled in Parliament and the first under the Public Financial Management Act, 2012. This statement is also sustained by the fact that this was the first year of a devolved system of governance. It outlines the broad strategic macroeconomic issues and fiscal framework, together with a summary of government spending plans, as a basis of the 2013/14 budget and the medium-term. According to the National Treasury, the BPS is published following Section 25 of the Public Finance Management Act, 2012 which states that in preparing the Budget Policy Statement, the National Treasury shall seek and take into account the views of The Commission on Revenue Allocation, County governments, Controller of Budget, The Parliamentary Service Commission, The Judicial Service Commission, The Public, and any other interested persons or groups.

There have been different budget policy statements, for instance, the 2014 statement was Economic Transformation for a Shared Prosperity in Kenya, 2016 was Consolidating Gains for a Prosperous Kenya, 2017 was consolidating economic gains in an environment of subdued global demand, and 2018 BPS is focusing on the "The Big Four" Plan of Vision 2030. According to TISA (2018), the national budget policy statement is framed in a manner that encroaches county functional mandates.

The International budget organization (2016), reviewed the budget statement 2016 and revealed the following concerning funding to county governments. The BPS 2016 proposes increasing the unconditional transfer to counties, known as the equitable share, from Ksh 259.8 billion to 280.3 billion in $2016 / 17$. The report showed a discrepancy in the figures given were 7.9 percent revenue growth was lower than the growth factor of 9.85 percent in the draft BPS and lower than 201510.4 percent. The report further revealed that the adjustment was significantly lower thanthe Commission on Revenue Allocation (CRA), which proposes a revenue growth factor of 15 percent in 2016/17 based on a three-year average. This raised concerns since the Treasury could not explain the source of its revenue growth factor or why it differs from CRA.

At the same time, Budget Policy Statement accelerates economic growth by sustaining macroeconomic stability; focusing on economic policies and structural reforms; and deepening investment in critical economic infrastructure aimed at promoting productivity and by extension facilitating the expansion of the private sector that will spur resilience necessary for employment creation and poverty reduction (National Treasury 2013). 
An equally significant budget statement for 2016 knows as Consolidating Gains for a Prosperous Kenya similarly contravenes regulation. This is pointed out in the International budget organization (2016) report which states that CRA recommended allocation for counties of Ksh 378 billion, Ksh 76 billion higher than Treasury's recommendation in the BPS 2016. The report further revealed that there was a significant difference in the number of conditional grants and their allocation. CRA proposes five new grants, while Treasury has only added one (the new emergency services grant). Although policies to guide the devolution process was developed and roles assigned to involved institutions, implementations of the same is lacking.

Despite this, a report by the Ministry of Devolution and Planning (2016) holds thatCounties are required to decentralize further to the smallest feasible units to achieve the objectives of devolution. However,the decentralization process has not been fully operationalized due to inadequate resources. Article 202 and 203 provide for the establishment of an agreed framework to guide intergovernmental fiscal transfers and allocation of resources between the two levels of Government in line with the Constitution and Public Finance Management Act of 2012

The National Treasury is responsible for funding resources including technical assistance for the activities to be undertaken under the devolution policy, provides leadership in directing, regulating, and facilitating the implementation of the policy concerning fiscal matters (Ministry of Devolution and Planning 2016). Report by KIPPRA (2016) revealed that 97 percent of the countieshad in place county budget review and outlook paper (CBROP), and county fiscal and strategy paper (CFSP).

The role of the Ministry of Devolution and Planning together with the National Treasury are required to build fiscal capacities in counties through a three-pronged approach: staff training, development of fiscal units, and support for the Integrated Financial Management Information System (IFMIS), (KIPPRA 2016).

Both the National Government and County governments under section 40 of the Public Finance Management Act, 2012, are required to prepare finance laws for parliamentary approval. Drawing from the statement above, the development of any kind requires an enabling environment to enhance the achievement of set goals. For this reason,access to resources will enablecounty governments to perform their functions through both own locally generated revenues and transfers from revenue raised nationally (CoG and UNDP 2015).

Furthermore, county governments are entitled to a minimum of 15 percent of all revenue that is collected nationally.National Treasury, controller of budget, the Senate, and the county assemblies have a role to play on matters of public finance. On the contrary, the report by CoG and UNDP (2015), revealed that the constitution does not provide clarity on the specific roles and responsibilities regarding public finance. For instance,Article 96 of the Constitution provides that the Senate exercises oversight over the revenue allocated to counties while article 185 (3) empowers county assemblies to exercise oversight over the county executive.

Evidence for in support of the above is that county governments have been experiencing delays in the release of monies from the National Treasury and thereby occasioning disruption of normal county business. The Standard Media (2016) report revealed funds delays by the National government to County governments. The Commission of Revenue Allocation (CRA) termed the issue as frustrating making it difficult for county governments to operate.

1.2.3 Threats on the independence of the judiciary whose position as a bulwark in the protection of devolution is under serious attack from political quarters

The Ministry of Devolution and Planning and UNDP (2016) report on policy in the devolved system of government, identified the judiciary as one of the implementers of devolution. Judiciary is required to exercise its constitutional mandate in clarifying roles, settling disputes, giving advisory opinions, and interpreting any questions arising from devolution policy. The International Development Law Organization (IDLO 2015) emphasized that the judiciary has the important role of giving effect to the constitutional provisions on devolution.

Presentation by Prof Ben Sihanya,to the Institute of Certified Public Accountants of Kenya (ICPAK) 20th Economic Symposium at the Hilton Hotel, Nairobi, February 24, 2012, expressed similar views when he stated that the judiciary is expected to play the role in ensuring accountability in the devolved government structure and the governance of devolved governments.

Consequently, the judiciary plays an equally significant role through the authority of the court to review executive and administrative conduct or actions of the state, state organs, state departments, and state officials. Concerning devolution, if the devolved government adopts an unaccountable system of governance, and makes decisions through such a system, the judiciary is expected to step in and review such decisions (Sihanya 2012).

Drawing from the discussion above, Sihanya(2012) insists that the Judiciary must ensure that devolved governments adopt principles of good governance, are accountable, and respect and follow the letter (or text) and spirit (or intendment) of the 2010 Constitution. He further stated that the judiciary should help ensure that the county government observes the rule of law in the governance process. It is recognized that the rule of law, upheld by an independent and incorruptible Judiciary, is an essential bulwark of democracy. It is important however not to assume thethreats on the independence of the judiciary whose position as a bulwark in the protection of devolution is under serious attack from political quarters (TISA 2018).

Whilst the discussion in the preceding paragraph the courts are specifically tasked to ensure that 
implementation accords with the text and spirit of the Constitution. For instance, IDLO (2015) affirms that the Supreme Court is given a special jurisdiction to give an advisory opinion (upon a request by a state organ) on any matter concerning a county government. Furthermore, courts have to settle disputes between the two levels of government as specified by the Constitution.

Report by IDLO (2015) further states that constitutional ambiguities and lack of clarity in vital areas of devolved governance require the intervention of the Judiciary, for instance, through advisory opinions. In some cases, the ambiguities in the Constitution formed the basis for conflicts and disputes that in many cases end up in court. Judiciary is required to provide further interpretation to guide specific processes to enhancedevolution.

There is also, however, a further point in the IDLO report (2015)expounding on the nature and extent of roles given to the two levels of government or other institutions, determination of resources that are allocated or due to the two levels of government, and the conduct of relations between institutions at the national and county level. These areamong other areas the constitution is not clear about; and the courts should be called upon to determine the meaning.

Nevertheless, constitutional ambiguities sometimes lead to the conflicting interpretation of the constitution by different actors in the implementation of devolution. This is especially when the political and institutional actors who oppose the principle of devolved governance choose convenient interpretation approaches that favor their interests. Such scenarios have led to conflicts about the meaning of constitutional provisions.

Ministry of Devolution and Planning and UNDP (2016) affirms this when they state that interpretation of the text on power dispensation to county governments has led to ambiguities and contested meanings of the constitutional framework. Due to this, there have been conflicts on various aspects of the implementation of devolved government, many of which have ended up in courts.

Ministry of Devolution and Planning and UNDP (2016) report further reveals that there were varied interpretations of the principle of separation of powers viewed against the system of checks and balances, as provided for in the constitution. Due to this, the institutions in charge of facilitating the devolution process have conflicted. For instance, parliament and the Judiciary, national assembly and the senate, national government and the county governments, county assemblies, and the county executives and county assemblies and the senate.

It is a challenge when the independence of the judiciary is threatened by the political quarters because this will affect the implementation of the devolved system of governance as per the constitution. There appears to be power supremacy overriding technical expertise. This means that the oversight and advisory roles to both levels of governments are not being administered as required by the law.

1.2.4 Underfunding of chapter 15 oversight institutions that serve to undermine their effectiveness in the protection of the constitution of Kenya.

Commissions and independent officesare among the institutions with sovereign power provided by the constitution specified in clause (2) and clause (3) of chapter fifteen of the constitution. The commissions are the Kenya National Human Rights and Equality Commission; the National Land Commission; the Independent Electoral and Boundaries Commission; the Parliamentary Service Commission; the Judicial Service Commission; the Commission on Revenue Allocation; the Public Service Commission; the Salaries and Remuneration Commission; the Teachers Service Commission; and the National Police Service Commission. The independent offices are the Auditor-General; and the Controller of Budget (Kenya Law Reform Commission, 2018).

The constitution also allocates responsibilities and powers to each of these institutions and one the responsibility for Constitutional Commissions and Independent Offices was to provide guidance and leadership in the implementation of devolution policy (Ministry of Devolution and Planning 2016). For instance, The National Land Commission is required to change fundamentally the law and practices about landholding and alienation, and remedy present and past historical land injustices.

The Salaries and Remuneration Commission has the responsibility of fixing salaries and allowances for politicians and public servants. The IEBCis responsible for ensuring fair and free elections. The Commission on Revenue Allocation must ensure a fair distribution of national funds to counties. The Auditor-General has to ensure scrupulous commitment to an elaborate framework of public finances and to prevent the misuse of state revenue Yash Pal Ghai (2016).

For these institutions to achieve their functions, they require to be funded a role that should be accomplished by theparliament to facilitate their function through the adequate allocation of funds to enable each commission and independent office to perform its functions. The law regarding the same states that the budget of each commission and independent office shall be a separate vote (KLRC, 2018). However according to TISA(2018) reporttheunderfunding of chapter 15 oversight institutions serves to undermine the effectiveness in the protection of the constitution of Kenya. Similarly, CoG 2016/2017 annual report revealed underfunding of the secretariat that led to some planned activities not get implemented affecting the achievement of devolution.

Daily Nation (2017) report on why independent teams and offices are under threat revealed that Sh550 million was slashed from the Auditor-General's budget for audit services. The Office of the Auditor-General cannot deliver its mandate without sufficient funds to do so. Judiciary was also affected when the supplementary budget, 
Sh1.95 billion meant for the dispensation of justice was slashed from the Judiciary's budget while the Judicial Service Commission (JSC) had its budget slashed by Sh306.7 million from Sh490.2 million.

Other than funding, the independence of these institutions is also under treat. There have been enacting laws to reduce the powers of the commissions, direct intimidation, and incapacitation through budgetary cuts. Daily Nation (2017) report further exposed the shrinking space for the independent commissions to be steady since the Executive, through legislation, has succeeded in clawing back some of the powers that they lost.

The 2015 Public Audit Act permittedthe Executive to take back the powers of the Auditor-General to hire and fire his staff. Also,the laws regarding the security of tenure of the Inspector-General of Police were enacted and the holder of the office was made subservient to the President who is currently the appointing authority. Similarly, the powers of the chairman of IEBC were reduced due to changes to the election laws. These challenges have impaired the functioning commissions and independent offices.

Report by the Ministry of Devolution and Planning in collaboration with UNDP (2016), emphasized that the responsibility and mandate for the achievement of the objects of devolution is a responsibility of the following state organs: parliament and the legislative assemblies in the county governments, the National Executive, the executive structures in the County Governments, the Judiciary and Independent Tribunals, Commissions and Independent Offices. The institution's collective responsibility to facilitate the achievement of objects of devolution can only be achieved if they play their roles without inference.

\subsubsection{The use of mechanisms in which the national government is planning to undertake Nairobi City} County functions without due process and intergovernmental agreements.

The Intergovernmental Relations Act, 2012 established the legal and institutional framework for consultation, cooperation, and dispute resolution between the national and county governments and amongst the county governments (Ministry of Devolution and Planning and UNDP 2016). Article 6(2) states that the two levels of government are distinct and inter-dependent and are expected to conduct their mutual relations based on consultation and cooperation.

The Intergovernmental Relations Act, 2012permitted the formation of intergovernmental relations bodies which include: National and County Government Coordinating Summit, the Intergovernmental Relations Technical Committee, and the Council of County Governors. However, each level of government is required to perform and exercises its powers in a manner that respects the functional and institutional integrity as well as the constitutional status of institutions of government at the other level.

Report by the Ministry of Devolution and Planning and UNDP (2016) further revealed that through the InterGovernmental Relation Act 2012intergovernmental sector forums on sector issues of common interest to the National and County Governments were formed. CoG annual report 2016/2017 revealed poor intergovernmental consultations as one of the challenges affecting devolution. The establishment of intergovernmental sector forums on sector issues of common interest to the National and County Governments is provided for in the InterGovernmental Relation Act 2012.

According to TISA (2018), the national government is planning to undertake Nairobi City County functions without due process and intergovernmental agreements. Evidence for the above statement is noted when the Constitution of Kenya (Amendment) Bill was proposed to remove Nairobi City County from the list of devolved units (Business Daily Africa 2017). A section of the proposed laws reads "There shall be a national capital city known as Nairobi, which shall be the seat of the national government,"It is important to note, however, that the Bill failed to sail through when the parliament adjourned to prepare for August elections and the senate through the Standing Orders 149, sub-section three, dictates that a Bill whose debate and passage is not concluded before the end of the term of the House shall lapse.

In this way, the CoG annual report (2017) pointed out anti-devolution legislation as one of the challenges affecting devolution. Bills that undermined devolution were tabled in parliament as revealed in the CoG report. Such Bill includes the County Governments Amendment Bill that sought to interfere with the tenure of County administrators; the Water Bill; the Health Bill; and the Kenya Roads Bill. CoGtermed the issue as an infringement on the functions of County Governments and there was a need for the two levels of government to respect the Constitution and consult on all matters to avoid conflict.

Report by Capital FM (2018) revealed that Governors from five counties envisioned in the Nairobi Metropolitan Area are proposing an amendment to the Nairobi Metropolitan Area Transport Authority (NAMATA) Bill to allow them to co-chair the Council alongside the Transport Cabinet Secretary. The current NAMATA Bill provides that the Cabinet Secretary responsible for Transport shall be the chairperson of the Council and the Deputy Chair of the Council shall be the Governor of Nairobi City County.

\subsection{Summary and Conclusion}

County governments are required to deliver their mandate assigned to them under the Fourth Schedule of the Constitution after the transition period for devolution ended on $4^{\text {th }}$ March 2016. These were the remarks of H-E JosphatNanokduring the induction of governors and deputy governors in December 2017. Indeed, these are the 
sentiments of the majority of Kenyans who are eagerly waiting to see the full functional county government without interference from the National Government.

As much as citizens would like to see services brought to them through the devolved system of governance, Governors have the responsibility of ensuring the devolution is achieved. "We are in the second phase of devolution. The time for mistakes is over." (Speech CoG Chairman Josphat Nanok 2017). The commitment by governors to deliver the best services to the community is facing a lot of hindrance from the national government. Legislative bills and budget policy statements that impinge devolution are hindrances to devolve system of governance. Issuance of threats to the judiciary thus affecting its independence interferes with the implementation of devolution.

Judiciary is required to interpret the law including the legislative billsthat aim at impinging devolution. Underfunding of oversight institutions and independent offices responsible for the implementation of devolution is a major blow to the devolved system of governance. Furthermore, laws have been enacted to reduce the power of these institutions. Nairobi Country is one of the 47 counties as provided in the constitution. Its functions are provided in the constitution and plan to take over the functions of Nairobi City County should go through an intergovernmental agreement.

The legitimacy of the County Government is enshrined in the constitution 2010 and there is a need to protect devolution from undue interference by all concerned institutions as well as citizens. The County governments' functional integrity and independence must be respected and collective responsibility by all institutions responsible for the implementation of devolution must be supported.

This paper revealed that the national government through its actions is a threat to devolution. Different mechanisms have been applied to harm the implementation of devolution. Both levels of government are required to genuinely work together for a common course- the success of devolution. Legislations should truly address the needs of the counties to ensure the realization of services at the grassroots. There should be sufficient and genuine support from the national government ministries, departments, and state agencies to the county governments.

Transfer of functions to the County Governments was to be enhanced through consequent and timely resource allocation to implement those functions. The roles of the majority of the institutions responsible for managing the implementation of devolution as mandated by the constitution 2010 have been interfered with by the National government. There was a delay in operations and execution of devolved functions from March 2013 to November 2013 due to late resource allocation. Delays in resource allocation have been repeated in the following years even after the devolution policy was developed to handle devolution challenges.

Late disbursement of funds, strained intra-governmental relations, threats to institutions responsible for devolution by enacting laws to reduce their power, direct intimidation, and incapacitation through budgetary cuts among other challenges has affected the achievement of devolution. The national government should provide full support to ministries, departments, and agencies in charge of the implementation of devolution.

It can be seen from the above analysis that power hierarchy/supremacy is overriding technical expertise thus affecting the implementation of devolution. Hierarchal observation is one of the power techniques that is produced as a result of disciplinary power as theorized by philosophers like Foucault, Gaventa cited in the works of Hoffman (2014). It can also be said that the executive has failed to build power relations between all stakeholders in the implementation of devolution as stated in the Intergovernmental Relations Act 2012.

\section{Reference}

Business Daily (2017).Bill to scrap Nairobi City County collapses. Available at www.business dailyafrica.com/news/counties.Accessed on $19^{\text {th }}$ March 2018.

Ngigi, S., \& Busolo, D. N. (2019). Devolution in Kenya: The Good, the Bad and the Ugly. Public Policy and Administration Research, 9(6). doi:10.7176/PPAR

Capital FM (2018). 5 Governors want greater say in Nairobi Metropolitan Area. Available at www.capitalfm.co.ke.Accessed on $18^{\text {th }}$ March 2018.

CoG\&UNDP(2015). Sectorial Policy and Legislative Analysis.Available at www.cog.go.ke. Accessed on $17^{\text {th }}$ March 2018

CoG (2017).Annual Report 2016/2017.Available at www.cog.go.ke.Accessed on 17 $7^{\text {th }}$ March 2018.

CoG (2017). Remarks by H.E. JosphatNanok, Chairman, Council of Governors and governor Turkana County: Induction of Governors and Deputy Governors Diani Reef Beach Hotel, Kwale County $13^{\text {th }}-17^{\text {th }}$ december, 2017.

CRA (2015).Constitutional and Legislative Policy Instructing the Drafting of County Revenue Laws in Kenya. Available at www.crakenya.org. Accessed on $15^{\text {th }}$ March 2018.

Daily Nation.(2017). Why independent teams and offices are under threat.Available at www.nation.co.ke/news. Accessed on $18^{\text {th }}$ March 2018.

Hoffman, M. (2014). Foucault and Power: The influence of Political Engagement on Theories of Power. New York: Bloomsbury. 
International Development Law Organization IDLO (2015).Animating Devolution in Kenya: The Role of the Judiciary Commentary and Analysis on Kenya Emerging Devolution Jurisprudence under the New Constitution.Available at www.idlo.int.Accessed on $18^{\text {th }}$ March 2018.

International Budget Organization (2016).Analysis of Budget Policy Statement 2016.Available at www.internationalbudget.org. Accessed on $17^{\text {th }}$ March 2017

Kenya Law Reform Commission KLRC (2013).Constitution of Kenya.Available at www.klrc.go.ke. Accessed on $19^{\text {th }}$ March 2018.

KIPPRA (2016).Status of Devolution in Kenya Consolidated Report.Available at www.kippra.or.ke.Accessed on $18^{\text {th }}$ March 2018

Ministry of Devolution and Planningand UNDP (2016).Policy on Devolved System of Government.Available at www.devolutionplanning.go.ke.Accessed on $17^{\text {th }}$ March 2018.

Shihanya, B.(2012). The Role of the Judiciary in the Accountability and Governance of the Devolved Government Structure.A presentation tothe Institute of Certified Public Accountant of Kenya(ICPAK)20 ${ }^{\text {th }}$ Economic Symposium at the Hilton HotelNairobi. Available at www.icpak.com.Accessed on $18^{\text {th }}$ March 2018.

The Institute for Social Accountability (TISA 2018).Publications.Available at www.tisa.or.ke.Accessed on $13^{\text {th }}$ March 2018.

The National Treasury (2013). Budget Policy Statement.Available at www.treasury.go.ke.Accessed on $17^{\text {th }}$ March 2018.

White, S. (2011). Government Decentralization in the $21^{\text {st }}$ Centaury. Centre for strategic and International Studies. Available www.csis.org. Accessed on $20^{\text {th }}$ June 2020.

YASH PAL GHAI. (2016)All you Need to Know About Independent Commissions, Offices.Available at www.katibainstitute.org.Accessed on $18^{\text {th }}$ March 2018. 